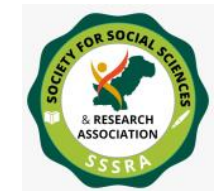

\title{
Comparative Analysis of Political Paradigms in the eras of Mikhail Gorbachev and Boris Yeltsin
}

\author{
Dr. Zobi Fatima \\ Assistant Professor \\ Iqra University \\ Karachi-Pakistan \\ zobi,fatima@iqra.edu.pk \\ Sumbul Yousuf \\ University of Karachi \\ Karachi-Pakistan \\ sumbulbinteyousuf@gmail.com \\ Hiba Zehra \\ Lecturer \\ Habib Girls College \\ Karachi-Pakistan \\ Hibazehra5@gmail.com
}

\begin{abstract}
Gorbachev and Boris Yeltsin were those Soviet leaders who wanted to establish a progressive society and liberal economic development, unlike the Stalinist system that prevailed in USSR for decades. However, Gorbachev was still deeply communist but Yeltsin wanted to replace the communist system with democratic and capitalist ideals. This study also highlights the dynamics which restricts both the leaders in fulfilling their goals. It also put a critique on their leadership style while considering the volatile nature of Russian society at home and agitations abroad. Both of these leaders failed in their aspirations due to the deep-rooted conservative social structure. The article also discusses the impact of the policies and leadership styles of the two on Russian society and politics. The research concluded that the period of Gorbachev and Yeltsin was just an episode in Russian history which did not bring any fruitful development. The succeeding years after Yeltsin somehow continued the same policies as were before Gorbachev.
\end{abstract}




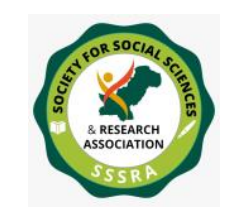

Pak. Journal of Int'L Affairs, Vol 4, Issue 2 (2021) Comparative Analysis of Political Paradigms ...

Key Words: USSR, Gorbachev, Russian Federation, Boris Yeltsin, Shock Therapy of Yeltsin

\section{Introduction}

Nature and style of political leadership play a major role in determining the destiny of a state. The personal opinions, biases, experiences, and backgrounds of leaders are key elements in shaping their stance regarding domestic and foreign policies. Nevertheless, the factors like international pressures, domestic interest, and pressure groups, agencies, and institutions as well as public opinion also impacted the performance of leaders. Thus, those promises and policies which they claim during election campaigns have been forgotten after winning the tenure and replaced by entirely different policies in the implementation phase (Horowitz 2018, 246-7). Due to the involvement of several factors, this phenomenon not only seems to be active in democratic societies but also in nondemocratic societies. The same has been found during the tenures of Mikhail Gorbachev and Boris Yeltsin when they steered the politics and economy of the USSR and Russian Federation, respectively.

It is important to notify that both of these leaders served their tenure during the chaotic period when Communism as an ideology was declining and the huge empire of the USSR was breaking down. One of the most unique and significant aspects of both leaders was that they both were willing to restructure USSR from age-old complex bureaucratic and rustic economic institutions which were no longer serving the needs and requirements of Russian society and its satellite states. However, they both differed in their methods, techniques, strategies, and policies. Therefore, in this article, an attempt has been made to conduct a comparative political commentary and analysis of both the leaders in yielding an open economy and free society in the USSR and Russian Federation, respectively.

This study has been designed to identify and analyze the factors which prevented Gorbachev and Yeltsin to accomplish their vision. For this purpose, the next section highlights the Gorbachev era, his personality as a reformist, his leadership style, domestic and foreign policies, the major challenges he faced during his reform journey, and why he failed to yield successful results out of them. Then, the tenure of Yeltsin has been analyzed in which his domestic policies in terms of economy and politics have considered, which are also known as 'shock therapy. Similarly, his approach towards foreign policy in terms of near-east the newly independent states from USSR and his deep inclination towards West, especially US, have critically evaluated.

\section{Mikhail Sergeyevich Gorbachev}




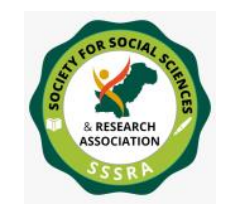

Pak. Journal of Int'L Affairs, Vol 4, Issue 2 (2021) Comparative Analysis of Political Paradigms ...

Disapproved and disliked in today's Russia (Masci 2017; Nikolskyi 2013; Taylor 2017) hailed in the West, Mikhail Sergeyevich Gorbachev is very unique in the field of leadership styles and personalities. He was neither a traitor to Russia who wanted to disintegrate the Union nor was a traditional power seeker which most ambitious leaders are. His era as General Secretary of the Soviet Union is, no doubt, one of the most remarkable events in history, as it brought tremendous changes to the world arena, the end of the Cold War being the most notable. Few, at home and abroad, anticipated the level of transformation that would follow the ascendancy of Gorbachev to power. Many in the West shoved off any possibility of real reform in the Soviet Union (Brown 1996), many in USSR were not ready to see things change the way Gorbachev's leadership made them see and dream for later.

At home, Gorbachev proved to be an effective reformist leader owing to his ability to persuade people in favor of such drastic changes while not being knocked out by ultraconservative forces. This required great political skills. His era ended up in the disintegration of the Soviet Union, which he never dreamt of, making him susceptible to intense criticism, at home, for being responsible for it. Although Gorbachev failed in his efforts to maintain the union, the greatest success of his leadership is manifested in the way the Soviet Union disintegrated. It is striking that such an event took place with relative peace in a country like Russia, having a history of violence. However, the longlasting changes that he envisioned never took place in a deep-rooted manner in Russian politics.

He was able to attract the interest of Western leaders ${ }^{1}$ and unlike any of his predecessors, he made public appearances abroad and shook hands with common people in the streets of Washington D.C. But he cannot be characterized as an apologist to the West, as he remained committed to Leninist socialism throughout his leadership tenure. His successor Boris Yeltsin fits nearer to the description of a leader appeasing West.

Gorbachev thought had successes and is remembered as a remarkable statesman, has been undermined because he failed in completion of his reform program. However, he did find the courage to confess what makes him regret it today. He talked extensively about this, after his resignation in his memoirs, speeches, and interviews with national and international newsgroups.

\footnotetext{
1 Margret Thatcher gave this famous remark after gorbachev's visit to London, "I like Gorbachev, we can do business with him", Thatcher, Margaret. Interview with John Cole. TV interview for BBC, December 17, 1984. 


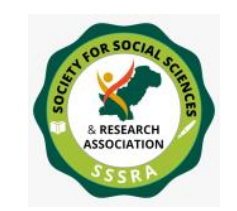

Pak. Journal of Int'L Affairs, Vol 4, Issue 2 (2021) Comparative Analysis of Political Paradigms ...

Gorbachev remained active in Communist politics during his student life. Like Lenin, he studied law which helped him learn the art of eloquent and effective speech (Sallnow 1989, 24). He was a critical thinker and reformist from the very start, but he wasn't a rebel either. Despite having the ability to think differently he remained faithful to the party. As Archie Brown puts it, he was a Marxist and also a Leninist, but "flexible and undogmatic" one, and thus was able to reach a different conclusion than the preconceived notions and stereotypical understanding.

During the last days of Stalin, Gorbachev started losing belief in many of his policies, when faith in Stalin was high and communism and Stalinism were akin. However, the change in policy and rhetoric when Khrushchev took over after Stalin's death interested Gorbachev the most. The changing environment of openness and greater knowledge about Stalin's terror impressed his ideas and attitude (Sallnow 1989, 29-30). Gorbachev remained in different positions of political power, finally becoming a full member of the politburo in 1980. During all these responsibilities, Gorbachev easily noticed and disapproved of the inefficiencies and corruption that was widespread in Soviet systems, and since by nature, he was an innovator and a problem solver he continuously sought to think on ideas for a change towards better. For example, Raisa's memoirs revealed that he was disgusted by the inefficient, unenthusiastic, and old Soviet bureaucracy while working for a district office in the 1960s. He commented that the environment is of accepting imprudently whatever prevailed.

The 'stability of cadres' policy during the Brezhnev era was a cause of greater concern and disappointment for people of somewhat liberal inclinations. This era was later commonly remembered as the period of stagnation and was marked by corruption, economic slowdown, and repression of dissidents. During this period, occurred the Prague spring and its forceful suppression. Gorbachev visited the area as the secretary of the central committee and was able to smell the air of resentment among the people on Soviet intervention. This experience led him to genuinely believe in the right of the union republics to have independence in their ways of development.

Although he was quite careful to keep his ideas to himself and only discuss with people most appropriate, he was able to impress officials with his new ideas, owing to his excellent communication skills. One of them was Fedor Kulakov and Yuri Andropov (Breslauer 2002). Former played a major role in bringing Gorbachev into politburo and later nominated him as his successor as Secretary-General. Although Andropov was not a reformer, yet he was honest and free from corruption, this was too the reason for the likeness of Gorbachev (Brown 1996). Gorbachev voiced his reform agenda in a speech in 1984 to the ideological worker's convention. This speech was very radical as compared to 


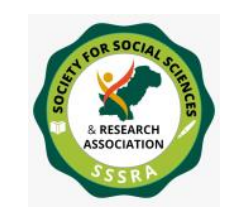

Pak. Journal of Int'L Affairs, Vol 4, Issue 2 (2021) Comparative Analysis of Political Paradigms ...

any of his wordings in the past and even during the first two years of his leadership he refrained to be this ambitious. He openly denounced the Brezhnevite ways of state affairs and put forward his ideas of 'democratization', 'acceleration', and 'perestroika', which would become the buzz words for his reforms. This brought more prominence to his position (Breslauer 2002, 48). However conservative forces in politburo prevented Gorbachev from succeeding Andropov. Only till the death of Chernenko environment in the politburo shifted more in favor of Gorbachev and he was elected as the General Secretary on 11 March 1985 (Brown 1996).

\subsection{Gorbachev as the Secretary-General}

After Lenin, Gorbachev was the first intellectual head of the USSR. He possessed knowledge and contemplation on the philosophies of Marx, Lenin, and Stalin and as mentioned earlier, he concluded his conclusions based on critical thinking. This equipped him well for the task to rally the people not only in the name of his reforms but for the sake of reviving the essence of Leninism-Marxism. He believed and made his people believe, that socialism has not failed, it only has not been utilized to its full potential and Stalinist and Brezhnevite ways of state affairs were the main obstacles in achieving a true prosperous socialist society.

The difficulty with which USSR managed to get a reformist leader depicted that reform would not be any easier. The first thing Gorbachev did was to form his team, yet no new team could be created out of nowhere for this task and the team prepared was still from the people already in the system. Secondly, the widespread intuition that change is needed did not coincide with any form of consensus on what type of change the USSR needs, resulting in a range of conflicting expectations that caused great differences in the forthcoming days.

Gorbachev appointed Ryzhkov as the chairman of the USSR council of ministers, similar to the prime minister, replacing an aged 'old guard' conservative Tikhonov. For foreign affairs, Gromyko was replaced by Shevardnadze, an old trusted friend of Gorbachev with whom he shared his political and reformist thoughts. Gromyko was made State president. Shevardnadze's appointment was a surprising one as he had no experience in foreign affairs, but he soon proved to be the right choice (Sallnow 1989, 34-36). Boris Yeltsin was promoted to the Moscow region by Gorbachev himself for his record of being tough on corruption and his criticism of centralization (Breslauer 2002, 33). Where the right appointments were necessary so were the right removals. Hence Romanov and Grishin were removed from the politburo. Some of the regional first secretaries were also replaced; the most notable of them was Kazakhstan's Dinmukhamed Kunaev. Several 


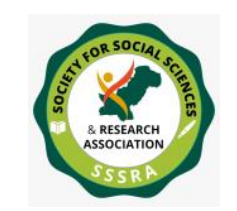

Pak. Journal of Int'L Affairs, Vol 4, Issue 2 (2021) Comparative Analysis of Political Paradigms ...

other important replacements and removals were made and a campaign against corrupt officials brought considerable change in personnel. This helped Gorbachev consolidate his power and embark on his reform program (Sallnow 1989).

In addition to the two most famous terms perestroika (restructuring) and glasnost (openness), two equally and perhaps more important terms used by Gorbachev, as part of his program were uskoreniye (acceleration) and democratization. The major concern for Gorbachev was to revive the economy when it was nearly dead, but he realized that it was not possible until a viable political change is brought, for that purpose he called for democratization. This demanded a well-informed public which requires openness i.e. Public should have access to the facts and criticism of state machinery or officials should be allowed. Gorbachev called these reforms aimed towards a 'developing socialism' as opposed to Brezhnev's claim of 'developed socialism. The main tenets of political reform included multi-candidate elections, separation of party and state apparatus and a fixed tenure period instead of lifetime appointments, thriving of democratic culture within the party (Sallnow 1989, 39).

He put forward his political reform vision in the $19^{\text {th }}$ party conference in June 1988 and from then onward the road to gradual reform was taken. Hence multi-candidate elections were held for the first time in March 1989 for the social organizations and constituencies and a representative institution named the Congress of People's Deputies and Supreme Soviet was formed based on these elections. The enthusiasm and turnout in these were elections were unprecedentedly high and the public, in general, had positive views on the process. The congress chose Gorbachev as the Chairman of the Supreme Soviet. There were, however, some intrinsic issues such as the elections for social organizations were unpopular on the ground that they undermined the concept of 'one person, one vote' because of the process through which candidates were registered. Several issues were raised in the congress itself, such as the continued dominance of the communist party over politics. Subsequently, changes in further elections were made. An important reform was the introduction of the executive presidency with strengthened swift decision-making powers. The proposal was defined as wanting an 'authoritative legislative organs, and a powerful president, and an energetic government and an independent legal system' but this was seen by some central committee members as Gorbachev's thrust towards 'personal dictatorship'. A majority accepting the proposal created the new position and Gorbachev was elected to it (White 1993).

The intractable stagnation of the economy proved to be one of the toughest challenges faced by Gorbachev and his reformist partners, despite economic reform being their priority. The Soviet economy under Brezhnev, inherited by Gorbachev (as Andropov and 


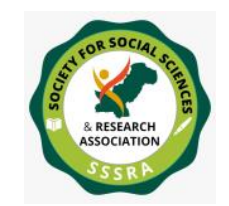

Pak. Journal of Int'L Affairs, Vol 4, Issue 2 (2021) Comparative Analysis of Political Paradigms ...

Chernenko had no effective time to change), had reached to point of zero or even negative growth rates. Soviet technology and product were in no way a match to the developing Asian economies, let alone the developed Western ones. The Soviet Union lagged far behind the world.

An analysis of Gorbachev's speeches that he delivered during his six years tenure shows that he was a 'socialist democrat'. He did not want to replace the planned economy with a liberal market economy. He wanted to restructure the economy with a modernized industrial base and inclusion of the needs of local enterprise and initiative (Miyanabe, 1989).

Gorbachev along with Ryzhkov well understood the need to decentralize the economy, but the transference of decision making to lower levels without an overall revolutionary change in the basic structure proved to be counterproductive. As Spring noted that the very reason for the failure of economic reform was piecemeal, where reforms were introduced in small stages that could not change things structurally, but on the other hand, no broomstick solution to bring a rapid change could be applied. Especially because Gorbachev, as Brown notes, was not an authoritarian ruler and sought to gain consensus for his actions, he was unable to enforce many reform actions swiftly. The simplest yet most evident example is the problem of subsidy on food products, Ryzhkov's proposal to reduce them was never approved by the Supreme Soviet. The problem of finding a balance between a controlled system and a market economy was also a difficult one. Very soon the economic reform especially and the whole process of perestroika generally became hostage to the fight between two emerging camps. One of those who wanted to rejuvenate the Soviet system through disciplinary measure but were not willing to change fundamentals, other were radical reformist, wanting fast liberal changes to be brought to the Soviet system. Breslauer $(2002,81)$ termed the former as conservative puritans (such as Ligachev and Ryzhkov) and the latter to be radicals (such as Boris Yeltsin). The drama on the 500-day program made the split appallingly clear. This program was put forward by the 'radicals', led by Boris Yeltsin, and laid down a plan to shift the whole of the Soviet economy to a market economy, with stages including privatization. This program was over-ambitious and would have led to a serious inflation problem resulting in unexpected political crises. The plan for economic reform led by Ryzhkov was brushed aside by the radicals as not too enough and cosmetic. They accused the Gorbachev administration to be restraining from bold reform steps.

By the end of 1990 Ryzhkov revealed his frustration in these words, "efforts to implement perestroika in its original form have failed" he continued explaining that "perestroika has wrecked established structures, both state and party ones, but nothing 


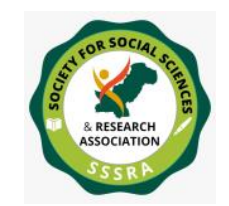

Pak. Journal of Int'L Affairs, Vol 4, Issue 2 (2021) Comparative Analysis of Political Paradigms ...

effective so far been created in exchange. This has directly affected the economy where there is neither a plan nor a market" (Spring 1991, 35).

A comparison of Gorbachev's 1984 ambitious speech and the way he moved forward after gaining power reveals that he remained cautious, slow, and incremental when acting on his ambitions. This was part of his democratic style leadership and but people like Boris Yeltsin who wanted more swift changes expressed fierce disagreement with this incremental approach. Hence Gorbachev was caught up in a bid to balance between the two. In doing so he inclined towards comparatively conservative elements, so-called 'puritans', by the end of his era, that is late 1990s and 1991.

The policy of glasnost was no doubt a memorable achievement as it gifted the people of the Soviet Union relative ease in not only having accessibility to true information but to voice their concerns. Polls in 1989 show the popularity that this policy gained among the public (White 1993, 94). Gorbachev thought glasnost to be an essential prerequisite to have a democratic system. As only a well-informed population with trust in its government can participate in it fully. Soviet history started being studied with increased honesty and the long history of persecution opened up. Soon after coming to power, Gorbachev released the famous dissident Andrey Sakharaov, a step gaining wide popularity, especially in the wider world. This was a clear signal for the policy of glasnost to have begun. It also gave the world a message that the Soviet Union was, in actual transforming.

One of the gravest of all regrets Gorbachev could have was that of the nationalist question, failure in it disintegrated the Soviet Union. It was as though the pre-Gorbachev Soviet Union had put a lid on the boiling cauldron of nationalist sentiments, crushed hard handedly if any of it managed to flow out. Gorbachev's initiative of openness and transferring greater autonomy to lower levels just permitted the republics to put up their demands. His vision was to "create the kind of Soviet Union that no one would want to leave' (Brown 1996, 267). This sort of union far from sight and his last efforts to come to some constitutional setting that would provide him time for this purpose proved to be futile. Gorbachev is blamed to act too slowly in responding to the crisis. Nevertheless, despite being appalled by the idea of losing any of the Soviet Union's territory, he refused to use force in any case. The cases where bloodshed occurred as a result of the use of force were without Gorbachev sanctioning the actions.

\subsection{Gorbachev's Foreign Policy}

Gorbachev's foreign policy was aimed at lessening the cold war tensions and a break on the arms race. Being able to run such a foreign policy, breaking away with the state 


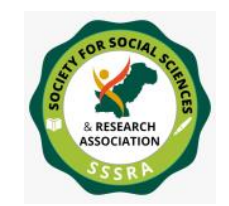

Pak. Journal of Int'L Affairs, Vol 4, Issue 2 (2021) Comparative Analysis of Political Paradigms ...

tradition in a xenophobic state like Russia, was no doubt a big success. He believed that the arms race was the biggest hurdle in Soviet Union's prosperity at home, as a large share of the economy and potential is spent there. Therefore, good at home can only be brought with the end of cold war tensions. He did not deliberate on foreign issues much before his era began, not even in the speech of 1984, but as soon as he became General Secretary he started persuading his team on the need of coming to peace with the world and how necessary it is for the Soviet Union itself. His international vision was 'idealist', speaking theoretically. He supported the UN for its role in the world, warned that nuclear war will result in no winners and that the interconnected world means that all nations suffer problems common to all, and they should be dealt with together. He longed for the much abandoned Helsinki process and while expressing his disapproval of making Europe a ground for weapons testing he called it 'our common home'. As for the communist world other than Russia, he expressed a desire to have brotherly relations with the 'great socialist community', especially China.

Gorbachev also possessed remarkable diplomatic skills, as he was able to impress very different people with his effective communication skills. Including Margret Thatcher, he was able to come on good terms with the hawkish US President Ronald Reagan, who famously called the Soviet Union 'an evil empire'. Four summits took place between the two leaders, the fourth one in Moscow, resulting in the first US president to have visited Moscow in fourteen years. The conclusion of the INF treaty was an important development and also was approved by the Soviet masses (White 1993). The boldest steps Gorbachev was able to take was to withdraw forces from Afghanistan which was a huge liability on its economy. The party program agreed in the $27^{\text {th }}$ congress in 1986 also retreated much in term of actively supporting the so-called 'national liberation movements and shifted its concern towards steps beneficial to the wider world community, and nevertheless promised to do whatever it could to further the socialist causes in the developing nations (White 1993, 216).

\subsection{Understanding the Failure of Gorbachev's Reform Agenda}

During 1991 the division in Soviet politics and society grew deeper and deeper, with Gorbachev's popularity on a steep decline. Economic life for the common man was worsening. Failure of the August coup in 1991 staged by the putsch was major because of the aggressive defense of the capital by Boris Yeltsin, but it also resulted in the lowered position of Gorbachev as a leader. Gorbachev gave way to Yeltsin by himself resigning in December 1991. The Communist party was abandoned, the Soviet Union was dissolved, and the Russian federation officially became the succeeding state (Brown 


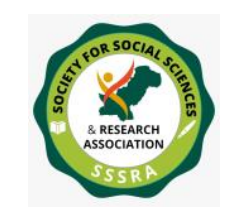

Pak. Journal of Int'L Affairs, Vol 4, Issue 2 (2021) Comparative Analysis of Political Paradigms ...

1996, 270-1). Yeltsin remained a harsh opponent of Gorbachev and used his agitation to gain popularity.

The reasons for the failure of Gorbachev's reform program are to be found nowhere other than the Soviet system itself. Extremely centralized and controlled economy, marred with stagnation and corruption in the bureaucratic system, with no checks and balances was bound to collapse at some moment. The need to reform was to be felt sooner or later. However, the intractable nature of the problem made it nearly impossible to create such a reform program that would overcome all hurdles economic, social, and ideological (Blaney and Gfoeller 1993). Serious criticism has been raised that there was a stark contrast in the ambitions of reform presented by Gorbachev, the true nature of Soviet problems, and the speed and thrust with which the reform should have been implemented. These inconsistencies as has been seen were raised because of the balance Gorbachev tried to maintain between reform and stability and to keep consensus among the conservatives and liberal circles. This of course didn't help yield results. Brar (1994, 1465) has commented on this dilemma in a very apt manner;

"He felt pushed towards the reforms he considered essential, but he also felt pulled back by the tradition from which he had come and to which, in a profound sense, he still belonged. While only he had to grapple with his predicament, his dilemmas were not of his own making. They were typical products of the hegemonic Bolshevik universe, particularly its organizational ethos."

Gorbachev's economic reform agenda was to remain within the ideological boundaries of socialism. That, however, restricted the scope of changes he could have brought, preventing them to be truly radical. The initial phase of reform was not radical at all and did not deal with the basic structural problems of the economy. Miyanabe, argues that Gorbachev's reform plan in his mind was to require a timespan of twenty to thirty years, with the final phase unleashed by 1992. However, things did not go this way. Serious food shortages in 1991 were both a symptom of problems in the reform agenda and a cause of public opinion going against Gorbachev and in favor of Boris Yeltsin (Miyanabe, 1989).

Despite the overall failure of Gorbachev's reform agenda, it cannot be denied that he became the reason that people in the Soviet Union (later Russia) were able to think and talk about ideas that no one could dare before Gorbachev. They voiced their agitation, albeit still in a very limited capacity because of the democratic backlash during the Putin era. That is an important tenet for a society to reform itself, in contrast to the downward reform approach taken by Gorbachev, where changes are done from above. 


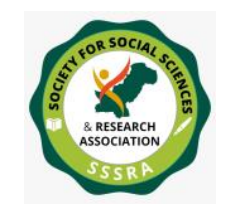

Pak. Journal of Int'L Affairs, Vol 4, Issue 2 (2021) Comparative Analysis of Political Paradigms ...

\section{Boris Yeltsin}

After the resignation of Gorbachev, Soviet Union disintegrated into multiple states in December 1991, and immediately after disintegration, Boris Yeltsin assumed the presidential office of the Russian Federation in January 1992 (Desai 2005, 87). As has been mentioned earlier that Gorbachev himself appointed Boris Yeltsin for the Moscow region due to his strict and discreet stance on corruption and strong opinion against centralization (Breslauer 2002, 33). Thus, a similar performance has been expected from Yeltsin when he assumed the presidential office. Nevertheless, soon these expectations began to evaporate, in the context of conflict between parliament and president when Yeltsin used his power to crush the democratic process. Therefore, the transitional struggle from Communism to democracy did not occur easily. Issues have continued to erupt between parliament and president throughout the year which became violent in October 1993. Consequently, Yeltsin evicted defector parliamentarians who refused to follow his decree and organized new elections and referendum for a new constitution, which re-designed the relations between the executive and legislative branches of government (Stoner-Weiss and McFaul 2009, 3; Rutland 1998, 696; Ross 2003, 23). It showed Yeltsin's enthusiasm towards the democratic system was verbal only because on the practical front he wanted to remain unchallenged, which indirectly re-established the centralized system in Russia of Soviet time.

Similarly, in the context of the economy, Yeltsin also wanted to transform the Russian economy and society like Gorbachev. His prime agenda was not just to transform but to eradicate the Communist economy and political system instead of reforming it. Hence, the democratic process - which was introduced by Gorbachev - was initially supported and promoted by Yeltsin but once again, he acted more in an autocratic manner and added despotic traits in democratic institutions of the Russian Federation (Desai 2005, 91-93). He introduced free speech but later reversed it due to fear of opposition. He cannot be viewed as a fully democratic leader because of his inability to bring accountability in government and to separate the powers of the institution. In fact, in the Constitution of 1993, the office of president has been designed in a more privileged manner than legislators. The president had more powers without a proper system of checks and balances (Morales 2007, 164). Another political mistake of Yeltsin was his inability to develop an independent judiciary and efficient system of court which prevented society from rule of law. Although, good laws have been drafted and adopted their implementation has remained bleak due to paying small attention to the building of police forces and civil service agencies (Rousso 2000, 109). 


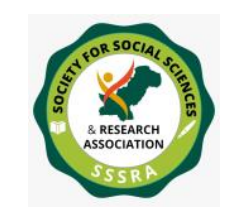

Pak. Journal of Int'L Affairs, Vol 4, Issue 2 (2021) Comparative Analysis of Political Paradigms ...

It was Gorbachev who brought Yeltsin within Politburo as First Party Secretary of Moscow city to help in reconstruction and rejuvenation of the Soviet Communist system. Nevertheless, the unstable nature of Gorbachev's policies with his perestroika program made Yeltsin impatient and he broke out with the former in his "secret speech" of October 1987. Afterward, Gorbachev made considerable efforts to cut Yeltsin from politics but it only strengthened Yeltsin's popularity more and more. In 1989, Yeltsin won a seat in the Soviet Union's Congress of People's Deputies and 1990 was elected as leader of a non-Communist faction in the Russian Congress of People's Deputies. From here, Yeltsin started a movement to create distinct political institutions in Russia including the office of president of which he was himself directly elected in June 1991 through free and fair elections (Stoner-Weiss and McFaul 2009, 9-10). However, in those early years, the transition was not that easy. Despite popular support, Yeltsin came across with failed attempt at a coup led by supporters of Gorbachev but resisted it with the help of loyal associates from the Russian White House. In the efforts to ensure the support of those loyal to him. Yeltsin wrote in his biography The Struggle for Russia;

Of course, for such a high-ranking military commander, things were not so simple. He was too closely involved with the coup plotters' operations. He was giving orders to move troops into Moscow and was running the military side of the coup. But at the same time, he was on our side (Yeltsin 1994, 59).

\subsection{Domestic Policies}

Yeltsin was strongly driven by the agenda that Soviet Communist ideology must be ended concerning authoritarian political rule and planned economy. For this purpose, his domestic policy framework had dominated by four features. First, Yeltsin's government intentionally avoided making negotiations with Communist legislators within parliament, though the framework of democratic legislation has already initiated in the elections of 1992 and the referendum of 1993. On the contrary, Yeltsin's team was in a constant tussle with Communists in Duma, the lower house of parliament. Second, Yeltsin was least concerned with the acceptance of his reforming policies among the masses. He appeared to be more technocratic than politically active (Desai 2005, 90-91). It has been asserted by the scholars that it was Yeltsin's arrogance that he failed to maintain a positive relationship with the Congress of People's Deputies. His policies failed because he never tried to build a coalition with the legislature nor he tried to win democratic reformers in parliament who initially helped him to elect as the first speaker of Congress of People's Deputies in 1990 (Stoner-Weiss and McFaul 2009, 13). This arrogance was not associated with Yeltsin only, almost every Soviet leader seemed to acquire this haughtiness after ascending to power, which intellectual called the honeymoon period. In this regard, though democratically elected, Yeltsin eventually became more autocratic 


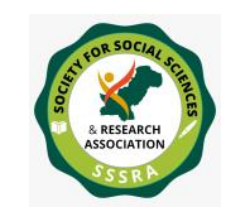

Pak. Journal of Int'L Affairs, Vol 4, Issue 2 (2021) Comparative Analysis of Political Paradigms ...

and hegemonic just like previous Soviet leaders (Breslauer 2002, 142). Third, the economic reforms had been initiated without considering the inadequacies of structural weaknesses in the Russian economic system. It resulted in discreet class division, high unemployment, and social agitation. Finally, the old political and economic system had been terminated with such ruthlessness that Yeltsin himself became apprehensive of possible political threats. Hence, to undermine them, he decided to appoint Vladimir Putin as his successor in the late 1990s (Desai 2005, 90-91).

One of the significant aspects of Yeltsin's domestic policy was Shock Therapy Reforms aimed at the political and economic setup of Russia. These were collectively applied and comprised of cutting the enormously high deficit in the budget, opening of the economy through foreign trade, privatization of national means of production, and liberalization of capital account within market-determined and unified rouble (Desai 2005, 94; Rutland 1998, 698; Aslund 1999; Cooper 2009, 3).

However, this approach of Shock Therapy drastically failed because Yeltsin's reformers failed to implement it in a give-and-take style. Furthermore, the situation continued to be exasperated due to the rigidity of reformers towards consensus building and this tradition has remained continued till the Duma elections of December 1999. Consequently, the strong public support of Yeltsin has continued to diminish over time because of the high costs of economic reforms on ordinary people (Desai 2005, 95). Another significant reason for the failure of these objectives was Yeltsin's inability to draft certain strategies to acquire these targets in a clear-cut manner. The ambiguity of the roadmap caused significant confusion and problems in economic policies (Breslauer 2002, 141).

The second major domestic policy of Yeltsin was the privatization of state-owned assets which was implemented from 1992 to 1994. It brought immense support for Yeltsin in the 1993 referendum and applied in two stages. In the first stage, vouchers worth 10,000 roubles have been distributed among the masses included women and children to purchase shares of private enterprises. In the second stage, the ownership stocks of the Russian government have been shared with some of the oligarchs within major nationalized companies, such as Norilsk Nickel (Desai 2005, 96; Cooper 2009, 3). Despite the initial popularity of the voucher program, public discontentment continued to rise against Yeltsin and his reforms. The prime reason was the incomplete information about the real worth of factories which had been put up for sale through vouchers. Also, the absence of electronic transactions brought uneasy outcomes for the public. Similarly, the scheme of loans-for-shares was also viewed with suspicion by the public who considered it a corrupt attempt of the government to snatch their assets which they made 


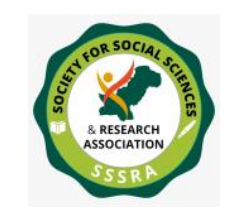

Pak. Journal of Int'L Affairs, Vol 4, Issue 2 (2021) Comparative Analysis of Political Paradigms ...

during Communist times (Stoner-Weiss and McFaul 2009, 12; Desai 2005, 97; Rutland 1998, 698; Aslund 1999, April 28).

Third, the budgetary policy was already in crisis since the 1990s. Although the Soviet government made offers for automatic subsidies through the existing budget, it was initiated based on those national enterprises which were huge monopolies but already in the loss. Initially, these reforms applied with consistency by factory managers and party bureaucrats. However, later budget management was interrupted by the absence of transparency in tax rates, obscurity in rules designed by federal, regional, and local hierarchies, and by the absence of efficient tax collection procedures (Desai 2005, 98).

It has been argued that the failure of these policies occurred due to reformers' inability to build proper economic institutions which are required to run the market economy, establish transparency in financial markets, develop a fluid market of labour, initiate a social safety net, and design reliable legal framework which can implement contracts, resolve disputes, monitor and ensure rights of shareholders, develop the competition, implement protection of property rights and curtail corruption. Rather, the reformers were more concerned with combating possible forces of Communism that they implemented the policies of market liberalization and privatization from above. Consequently, it failed to penetrate in Russian economy and society and brought drastic failures (Rousso 2000, 110).

It has been fairly observed that Yeltsin was highly impatient about the Russian system and wanted to change it as early as possible. He despised the steadiness in Russia's domestic policy environment which can be gathered through his feelings which he narrated in his biography that;

"Not a single reform, effort in Russia has ever been completed. (...) In Russia, not two land reforms, three revolutions, Lenin's new economic policy, Stalin's industrialization, Khrushchev's thaw, or Kosygin's quiet reforms changed anything fundamental in Russia" (Yeltsin 1994, 145).

In light of the above statement, it has been analyzed that the efforts of Yeltsin were also not successful. It might be due to the reason that those policies were highly superficial who tend to bring change on a surface level. None of them was designed to address deeprooted economic and political issues nor to bring long-lasting change in Russian society. However, those policies which tended to bring considerable transformation, their implementation have been hindered by Yeltsin's greed for maximum power and control. Despite all these issues and weaknesses, the Russian rouble was considered as one of the most stable currencies of the world by the end of the 1990s but it was all illusionary. The 


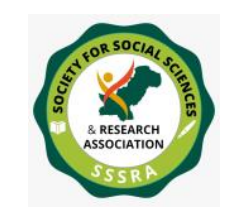

Pak. Journal of Int'L Affairs, Vol 4, Issue 2 (2021) Comparative Analysis of Political Paradigms ...

actual crisis demonstrated itself in August of 1998 which became a strong reason for the end of Yeltsin's period in the Russian Federation (Rousso 2000, 113).

\subsection{Foreign Policy}

After assuming the office of president in 1992, Yeltsin appointed Andrei Kozyrev as Foreign Minister in the early months of 1992. Kozyrev, like Yeltsin, was intended to design conditions in which the new Russian Federation could prosper hence he emphasized Russian membership in economic institutions and clubs of democratic and developed states. He inculcated the idea of "liberal Westernization" in Russian national interests. Hence, the foreign policy was designed on the ideas of human rights promotion, security of universal values, and protection of global economic, nuclear, and environmental setup (Donaldson 2000, 289-90).

In the context of Boris Yeltsin, Russian foreign policy came across unique trends and developments. It has been observed that personality-leadership and executive relations mattered more as compare to parliament's or political parties' influence on foreign policy. This feature was also dominant in foreign policy administered by Boris Yeltsin (Kastner 2008, 29; Donaldson 2000, 297). One of the significant pieces of evidence given by Yeltsin himself in his autobiography The Struggle for Russia about relationship with US President, George H.W. Bush;

George Bush and I established very friendly relations. Barbara Bush also calls now and then. I hope that she will come to visit, and Nina will host her well, and she will have a wonderful time. Bush and I agreed to play tennis. It's sure to be a very tough match (Yeltsin 1994, 138).

Second, it has been seen that several small interest groups began to demonstrate a strong influence on foreign policy (Kastner 2008, 29-30). Consequently, the role of parliament was extremely limited in nature (Donaldson 2000, 299). It could not control the massive foreign policy decisions as it should have due to limited powers assigned to it by President and the constitution. Third, the president had foreign policy competence but its implementation was hugely dependent on bureaucratic actors. The absence of a bridging coordination mechanism generated confusion and vaguely distributed foreign policy tasks among multiple and institutional rivalries. Hence, it used to delay the timely decision making and caused multiple stances on foreign policy instead of the single front of the Russian Federation. Finally, the making of foreign policy was hugely drawn from the domestic economic situation instead of security concerns. In this regard, the OECD 


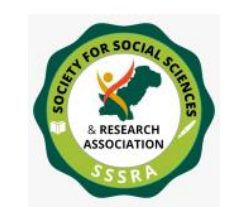

Pak. Journal of Int'L Affairs, Vol 4, Issue 2 (2021) Comparative Analysis of Political Paradigms ...

countries have prioritized more on the place of newly independent states in the immediate neighborhood of the Russian Federation (Kastner 2008, 302).

Commonwealth of Independent States (CISs) was a cluster of states which were earlier Soviet republics. After the formation of the Russian Federation, their status immediately changed from domestic states to foreign states. With the help of presidents of Belarus and Ukraine, Yeltsin has put the foundation of CIS which is comprised of Central Asian states, Moldova and Caucasus. The structure and framework of this organization were extremely vague and dense but one thing was clear that Russia was intended to use it in a security context instead of an economic one (Kastner 2008, 302).

As far as relations with the West, the US-Russia relations were the most significant concern for Yeltsin. It is necessary to highlight that the foreign policy of Yeltsin was determined by domestic economic needs. In this regard, the US appeared to be the only country that could provide the required economic assistance to Russia. Hence, the initiative of positive relationship taken by Gorbachev has further expanded by Yeltsin (Lukic and Lynch 1996, 235; Donaldson 2000, 305). In this regard, the relationship with the West is highly prioritized by considering it as a major ally for the political development and economic assistance of Russia. It was an outcome of Kozyrev diplomacy that Russia somehow accepted the unipolarity of the US (CIDOB 2010, 224). Until 1993, this stance of Yeltsin had continued. Nevertheless, in the meantime, criticism against Yeltsin intensified due to the failure of Shock Therapy which also revealed the minuscule level of economic assistance provided by the US to Russia. Also, the Russian public began to question the US intentions in light of its policy towards Yugoslavia and airstrike on Iraq (Lukic and Lynch 1996, 308). The inclination towards the US was further reduced during the Bosnian crisis. Russia was strongly supporting Serbia in its war against Croats and Muslims in Bosnia. It not only opposed Western military intervention but also thwarted efforts of lifting the arms embargo on Bosnia. However, this stance was difficult to maintain during 1994-95 due to the severity of the crisis and constant attacks on the UN's "safe havens" in the region. Thus, in 1995, Yeltsin was forced to implement Dayton Accords by President Clinton (Lukic and Lynch 1996, 308). Similarly, in the post-Dayton Accords period, the expansion of NATO was another worrying concern for Russia. In this regard, the new foreign minister, Yevgeniy Primakov followed the approach of multipolarity, unlike Kozyrev. The situation in the Balkans and the constant expansion of NATO was the prime cause behind it (CIDOB 2010, 224). Throughout the Cold War, NATO has been viewed as an adversary by the Russian government, military, and public. Hence, it was difficult for Russia to deal with NATO expansion as it was a matter of national pride. Eventually, in 1997 certain agreements have signed to maintain mutual and peaceful relations (Lukic and Lynch 


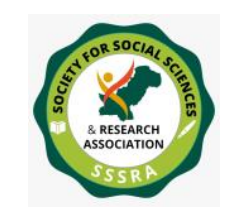

Pak. Journal of Int'L Affairs, Vol 4, Issue 2 (2021) Comparative Analysis of Political Paradigms ...

1996, 309-10). Nevertheless, in the post-Soviet world, Russia has first time emerged as challenging US hegemony in the global political environment and tried to counterbalance it (CIDOB 2010, 224).

During the times of Boris Yeltsin, Russia considered itself an important part of Europe and tried to extract maximum benefits out of it (Sherr and Chatham House, 2016). Furthermore, it has been found that the Russian government garnered many benefits from OECD countries as compare to CISs. For instance, European Union (EU) had cut down tariffs on some Russian goods and the US gave Russia MFN status in 1992 (Kastner 2008, 32). Similarly, hopes have been raised that Russia would play a major role in integrating EU and CIS (Commonwealth of Independent States). On the contrary, these ideals have eventually disintegrated due to Russian domestic opposition for market reforms, resurfacing of Russian nationalism, and the independent course of foreign relations by CIS (Sherr and Chatham House, 2016).

Another important element associated with Russian foreign policy under Yeltsin was that Russia was not only determined to prove itself as part of Europe due to economic factors but it also had deep concerns with its Slavic identity traits. Yeltsin was trying to balance his foreign policy between these two distinct poles which resulted in erratic, incoherent, and uncoordinated foreign policy (Timmins 2003, 82).

However, the efforts of maintaining positive and beneficial relations with Europe had been made by both Russian Foreign Ministers Andrei Kozyrev and Yevgeny Primakov, respectively. They both attempted to maintain the national pride and national interests of Russia along with cooperation with the West. Nevertheless, the situations were highly challenging concerning issues in Yugoslavia and the Middle East. Thus, Russia took several steps forward and backward, simultaneously in foreign policy matters towards the US and Europe (Breslauer 2003, 189; Lane 2013, 189). According to political pundits, the presence of NATO in Europe played a detrimental role in designing the relationship between Russia and the continent. After the end of the Cold War, the Warsaw Pact has been dissolved and Russia intended to see similar results for NATO as well. On the contrary, the organization continued to work with new tasks and targets which were viewed with significant suspicion and concern. Nevertheless, Russia got successful in preventing NATO forces to intervene in the matter of Kosovo based on the UN Charter which promotes ideals of territorial integrity. Similarly, it also made efforts to bring peace between Yugoslavia and NATO which forced the latter to withdraw forces from Kosovo (Oldberg 2013, 33). Similarly, the EU also recognized the Russian efforts regarding stable development concerning the protection of basic human rights and democracy. EU helped Russia in acquiring and maintaining democratic values, norms, 


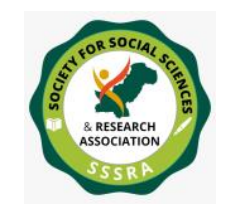

Pak. Journal of Int'L Affairs, Vol 4, Issue 2 (2021) Comparative Analysis of Political Paradigms ...

and practices (Schmidt-Felzmann, 2015, 602). Yeltsin assumed that the breakup of the Soviet Union would bring Russia as an equal partner of the Western world. The democratic world and international institutions of the Capitalist economy praised Yeltsin for his efforts for democratizing Russia but they never presumed it as an equal partner due to its Soviet Legacy. Therefore, Russia only remained as their puppet instead of an equal partner. This stance has later changed by Putin who began to challenge NATO and US hegemony (Gidadhubli 2007, 1820).

\section{Discussion \& Conclusion}

Gorbachev as a leader exhibited great skills in motivating and inspiring people towards a change and he used his persuading skills to gather his team on different issues. He engaged in writing and communicated his ideas with the public extensively through books, memoirs, and reports. His positive outlook helped him move on for a long time. As regards his cautious attitude, Gorbachev himself looks back and wished he could have implemented reform faster. In an interview, he went to the extent expressing that he now thinks, why he didn't abandon the Communist party then and formed his new one as the party apparatus was making reform difficult. ${ }^{2}$ The failure in achieving the results of perestroika and a saddening breakup of the Soviet Union, as discussed earlier, was not solely Gorbachev's leadership's failure, but was bound to happen given the long-festering issues of the Union. It was Yeltsin's signature and recognition of independent Estonia that caused the snowball effect and resulted in the rapid foundation of new states which were satellite states of the Soviet Union. In this regard, the US role in helping Baltic States to get independence and Gorbachev's resignation further fueled the disintegration of the USSR (Gidadhubli 2007, 1819). The Soviet system (political, social, economic, and ideological) was kept together on a very fragile basis; any meaningful reform was bound to end up disastrously, thanks to Gorbachev's leadership that it happened with little bloodshed.

Based on the above discussion, it has been asserted that Yeltsin had pure intentions but impure tactics and immature strategies. Unlike Gorbachev, he immediately wanted to convert Russian society to a Western model. His urgency and impatience, to bring drastic change proved a basic deterrent in his tenure. The close analysis of his both domestic and foreign policies reveal that he intended to make Russia economically sound and stable but he wanted to do it on his terms. He was not willing to recognize the ground realities

\footnotetext{
${ }^{2}$ Interview by Jonathan Steele, The Guardian; Mikhail Gorbachev: I should have abandoned the Communist party earlier. August 16, 2011. https://www.theguardian.com/world/2011/aug/16/gorbachev-guardian-interview
} 


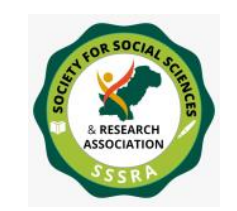

Pak. Journal of Int'L Affairs, Vol 4, Issue 2 (2021) Comparative Analysis of Political Paradigms ...

of Russian society and Soviet legacies which were deep-rooted. Due to this reason, he implemented Shock Therapy reforms at home and at abroad he tried to maintain peace with the West. Nevertheless, for Russian society, these policies proved faulty and only resulted in creating few rich oligarchs (Gidadhubli 2007, 1818; Friedberg 2017, 23). Some scholars have voiced the opinion that the foreign policy of Yeltsin was incoherent, impulsive, and deprived of coordination with Newly Independent States broken from the USSR. Yeltsin gave extra significance to those foreign leaders with whom he had personal relations. Consequently, he often contradicted or changed the stance of foreign policy without considering the long-term consequences in the international political environment (Morales 2007, 164).

Yeltsin prioritized the West concerning economic benefits instead of security concerns. However, the relationship with former Soviet states was more security-oriented instead of economic (Kastner 2008, 39). Gorbachev in his book "New Russia" expressed his concerns on the backlash of democratic practices in Russia, not only under Yeltsin but also under Putin. He also complained that the West namely the US assured that a freed Eastern Europe would not be taken advantage of, yet NATO expansion continued. This in turn exacerbated the fear of external threats among Russians, contributing negatively to internal democratizing developments (Gorbachev, 2016). Usually, Western media - often ignores Gorbachev - and highly praise Yeltsin for his resignation and stepping down from power as his democratic spirit. However, it was unpopular public opinion, highly volatile economic environment, imbalanced foreign policy, and his incapability of governance that he handed over his powers to his protégé, Putin (Gidadhubli 2007, 1819). It has been analyzed that the period of Gorbachev and Yeltsin was only a single episode of bringing a free economy and open society. Russian society was not that patient to wait for Gorbachev's policies to get functional and bring real change. Similarly, it was also not too eager and ready to process the policies of Yeltsin. Besides, the impatience of Yeltsin further destroyed those developments which managed to succeed under Gorbachev. It has been observed that after the episode of these two leaders, the existing leadership of Russia somehow continued the old Soviet legacies and caused relapses in key political and economic policies.

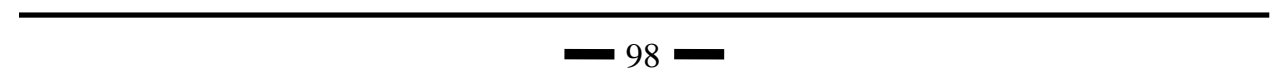


Comparative Analysis of Political Paradigms ...

\section{References}

Aslund, A. (1999, April 28). Why has Russia's Economic Transformation been so Arduous? Carnegie Endowment for International Peace. https://carnegieendowment.org/1999/04/28/why-has-russia-s-economictransformation-been-so-arduous-pub-201.

Blaney, J., \& Gfoeller, M. (1993). Lessons from the Failure of Perestroika. Political Science Quarterly, 108(3), 481-496.

Brar, B. (1994). Assessing Gorbachev. Economic and Political Weekly, 29(24), 1465-1475.

Breslauer, G. W. (2000). Russia, the Baltic States, and East-West Relations in Europe, in Vello Pettai \& Jan.

Breslauer, G. W. (2002). Gorbachev and Yeltsin as leaders. Cambridge University Press.

Brown, A. (1997). The Gorbachev Factor. Oxford: Oxford University Press.

CIDOB. (2010) Russian Federation: Country Profile, CIDOB International Year Book: Russian Federation, Country Profile.

Cooper, W. H. (2009, June). Russia's economic performance and policies and their implications for the United States. Library of Congress Washington Dc Congressional Research Service.

Desai, P. (2005). Russian retrospectives on reforms from Yeltsin to Putin. Journal of Economic Perspectives, 19(1), 87-106.

Donaldson, R. H. (1999). Boris yeltsin's foreign policy legacy. Tulsa Journal of Comparative and International Law. 7, 285.

Friedberg, A. L. (2017). The Authoritarian Challenge: China, Russia, and the Threat to the Liberal International Order. Sasakawa Peace Foundation, August.

Gidadhubli, R. G. (2007). Boris Yeltsin's Controversial Legacy. Economic and Political Weekly, 1818-1820.

Gorbachev, M. (2016). The New Russia. John Wiley \& Sons. 


\section{Pak. Journal of Int'L Affairs, Vol 4, Issue 2 (2021) Comparative Analysis of Political Paradigms ...}

Horowitz, M. C. (2018). Leaders, Leadership, and International Security. The Oxford Handbook of International Security, 246.

Kästner, A. (2008). From chaos to pragmatism? The domestic dimension of Russian foreign policy 1991-2008 (Vol. 19, p. 61). DEU.

Lane, D. (2013). The Capitalist Transformation of State Socialism: The Making and breaking of state socialist society, and what followed. Routledge.

Lo, B. (2002). Russian Foreign Policy in the Post-Soviet Era: Reality, Illusion and Mythmaking. Springer.

Lukic, R., \& Lynch, A. (1996). Europe from the Balkans to the Urals: The Disintegration of Yugoslavia and the Soviet Union. Oxford University Press.

Masci, D. (2017). In Russia, Nostalgia for Soviet Union and positive feelings about Stalin. Pew Research Center, 29.

Miyanabe, N. (1989). The "Perestroika" of Soviet Retail Price System (1). Economic Review, 40(1), 52-64.

Morales, J. (2007). The Yeltsin Presidency in Retrospect: Myths, Realities and Lessons to be Learned. Revista UNISCI, (14), 161-165.

Oldberg, I. (2013). Foreign Policy Priorities under Putin: a tour d'horizon. In Russia as a Great Power (pp. 47-74). Routledge.

Pettai, V., \& Zielonka, J. (Eds.). (2003). The Road to the European Union: Volume 2: Estonia, Latvia and Lithuania. Manchester University Press.

Ross, C. (2003). Federalism and Democratisation in Russia. Manchester University Press.

Rousso, A. (2000). Russia's Transformation: The Prospects for Democracy. The Brown Journal of World Affairs, 7(1), 107-127.

RT News:Question More (2013, May 22). Russians Name Brezhnev Best 20th-Century Leader, Gorbachev Worst. RT News https://www.rt.com/politics/brezhnev-stalingorbachev-Soviet-638/

Rutland, P. (1998). The Boris Yeltsin of History. Demokratizatsiya: The Journal of PostSoviet Democratization, 6, 692-701. 
Comparative Analysis of Political Paradigms ...

Sallnow, J. (1989). Reform in the Soviet Union: Glasnost and the Future. Printer Publishers London.

Schmidt-Felzmann, A. (2015). European foreign policy towards Russia: challenges, lessons and future avenues for research. The SAGE Handbook of European Foreign Policy, London: Sage Publications.

Sherr, J. (2016, January 5). How Russia's Relationship with Europe has Evolved, $B B C$ News, http://www.bbc.com/news/world-europe-35154633

Spring, D. W. (Ed.). (1991). The Impact of Gorbachev: The First Phase, 1985-90. London: Pinter.

Stoner-Weiss, K., \& McFaul, M. (2009). Domestic and international influences on the collapse of the Soviet Union (1991) and Russia's initial transition to democracy (1993).Center on Democracy, Development, and The Rule of Law Freeman Spogli Institute for International Studies.

Taylor, A. (2017, February 15). Positive Views of Stalin among Russians Reach 16 Year High Poll. The Washington Post, https://www.washingtonpost.com/news/worldviews/wp/2017/02/15/positive-viewsof-stalin-among-russians-reach-16-year-high-poll-shows/?utm_term=.91be90191ab5

Timmins, G. (2002). Strategic or Pragmatic Partnership? The European Union's policy towards Russia since the end of the Cold War. European Security, 11(4), 78-95.

White, S. (1993). After Gorbachev (No. 3). Cambridge University Press.

Yeltsin, B. (1994). The Struggle for Russia. New York: Random House Inc. 